\title{
Peningkatan Hasil Belajar Siswa Melalui Pendekatan Cooperative Learning Tipe Student Team Achievement Division (STAD) Pada Mata Pelajaran IPS Kelas IV SD Negeri 135 Rejang Lebong
}

\author{
Emmi Fauziah \\ SD Negeri 135 Rejang Lebong \\ pirmansah_pipin@yahoo.co.id
}

\begin{abstract}
This research is motivated by the phenomena that occur in the learning process, especially the subjects of Social Sciences, including the poor communication between teachers and students, teacher domination which has passive impact on students in the classroom, and lack of reinforcement and reward for students. Classroom Action Research (CAR) consists of 2 cycles, each of which consists of two to three meetings. The stages in each cycle consist of the stages of planning, implementation, observation / observation, and reflection. The research subjects were fourth grade students of Rejang Lebong Elementary School 135 consisting of 24 people in the 2016/2017 school year. The results were obtained that in the first cycle students' learning outcomes averaged 60.79 and the percentage of classical learning completeness was $58.33 \%$. In the second cycle there were no more weaknesses that occurred in cycle I. The learning outcomes in the second cycle obtained an average of 72.47 with the percentage of classical learning completeness $87.5 \%$. This fulfills the completeness criteria, ie $85 \%$ of students get a value of ,07.0 and the learning process is said to be completed individually if students get a value of $\geq 7$. Based on the results of these studies, the Cooperative Learning Approach Student Team Achievement Division (STAD) type can improve learning outcomes, student activities, and teacher activities and the quality of the social studies learning process.
\end{abstract}

Keywords: Learning Outcomes, Cooperative Learning Approach Type Student Team Achievement Division

Abstrak: Penelitian ini dilatar belakangi oleh fenomena yang terjadi dalam proses pembelajaran khususnya mata pelajaran Ilmu Pengetahuan Sosial, diantaranya yakni buruknya komunikasi antara guru dan siswa, dominasi guru yang berdampak pasifnya siswa di dalam kelas, serta kurangnya penguatan dan reward terhadap siswa. Penelitian

AR-RIAYAH : Jurnal Pendidikan Dasar vol. 2, no. 2, 2018

STAIN Curup - Bengkulu| pISSN2580-362X;e ISSN2580-3611

http://journal.staincurup.ac.id/index.php/JPD 
Tindakan Kelas (PTK) ini terdiri dari 2 siklus, yang setiap siklusnya terdiri dari dua sampai tiga kali petemuan. Tahapan pada setiap siklus terdiri atas tahap perencanaan, pelaksanaan, pengamatan/observasi, dan refleksi. Subjek penelitiannya adalah siswa kelas IV SD Negeri 135 Rejang Lebong yang terdiri dari 24 orang pada tahun pelajaran 2016/2017. Hasilnya diperoleh bahwa pada siklus I hasil belajar siswa rata-rata 60,79 dan persentase ketuntasan belajar klasikal 58,33\%. Pada siklus II tidak terdapat lagi kelemahan-kelemahan yang terjadi pada siklus I. Hasil belajar pada siklus II diperoleh rata-rata 72,47 dengan persentase ketuntasan belajar klasikal 87,5 \%. Hal ini memenuhi keriteria ketuntasan, yaitu $85 \%$ siswa memperoleh nilai $\geq 7,0$ dan proses pembelajaran dikatakan tuntas secara individu apabila siswa memperoleh nilai $\geq 7$. Berdasarkan hasil penelitian tersebut maka Pendekatan Cooperative Learning Tipe Student Team Achievement Division (STAD) mampu meningkatkan hasil belajar, aktivitas siswa, dan aktivitas guru serta kualitas proses pembelajaran IPS.

Kata Kunci: Hasil Belajar, Pendekatan Cooperative Learning Tipe Student Team Achievement Division

\section{PENDAHULUAN}

Pendidikan merupakan salah satu aspek yang menentukan masa depan bangsa. Semakin maju pendidikan maka akan semakin maju pula suatu bangsa. Menurut Jean Peaget Pendidikan berarti menghasilkan, mencipta, sekalipun tidak layak, sekalipun suatu penciptaan dibatasi oleh pembandingan dengan penciptaan yang lain. ${ }^{1}$ Pada Sekolah Dasar, pendidikan berfungsi memberikan bekal dasar pengembangan kehidupan, baik kehidupan pribadi maupun masyarakat, mempersiapkan anak didik mengikuti pendidikan ketingkat menengah pertama serta membekali sikap, pengetahuan dan keterampilan dasar. Dalam pendidikan dasar guru berperan penuh untuk mengubah perilaku siswa, karena anak SD akan menerima apapun yang diberikan oleh guru tanpa mempertimbangkan mana yang benar dan mana yang salah. Maka dari itu seorang guru dituntut untuk profesional dalam mendidik para peserta didik di sekolah.

Salah satu program pengajaran di jenjang pendidikan yaitu Ilmu Pengetahuan Sosial. IPS memfokuskan kajiannya kepada hubungan antar

\footnotetext{
${ }^{1}$ Sagala, Konsep dan Makna Pembelajaran, (Alfabeta:Bandung,2006),.1-3.
} 
manusia dan proses membantu pengembangan kemampuan dalam hubungan tersebut. Pengetahuan, keterampilan dan sikap yang dikembangkan melalui kajian ini ditujukan untuk mencapai keserasian dan keselarasan dalam kehidupan masyarakat. Pendidikan IPS sudah lama dikembangkan dan dilaksanakan dalam kurikulum-kurikulum di Indonesia, khususnya pada jenjang pendidikan dasar. Ilmu Pengetahuan Sosial (IPS) sebagai salah satu bidang studi yang memiliki tujuan membekali siswa untuk mengembangkan penalarannya di samping aspek nilai moral, banyak memuat materi sosial yang bersifat hapalan sehingga pengetahuan dan informasi yang di terima siswa sebatas produk hapalan. ${ }^{2}$

Menurut sebagian besar siswa mata pelajaran Ilmu Pengatahuan Sosial merupakan pelajaran yang sulit dipahami, walaupun secara langsung ataupun tidak langsung dalam kehidupan sehari-hari kita dapat menjumpai fenomenafenomena yang berhubungan dan berkaitan dengan ilmu pengetahuan sosial. Terkadang kita menemukan siswa mengeluh jika dihadapkan pada mata pelajaran Ilmu Pengetahuan Sosial, karena mereka menganggap prosesnya adalah menghapal dan menghapal.

Berdasarkan hasil observasi dan wawancara dengan guru di sekolah diperoleh permasalahan dalam pembelajaran IPS antara lain: (1) selama proses pembelajaran, informasi bersumber dari guru dan kurang ada interaksi dari siswa, (2) guru lebih sering berbicara dan ,menyampaikan informasi atau materi jarang sekali memberikan kesempatan kepada siswa untuk bertanya, (3) metode yang banyak digunakan adalah metode ceramah (4) Siswa jarang diberikan kesempatan untuk memecahkan masalah sendiri (5) Guru jarang sekali memberikan penguatan atau pun penghargaan kepada siswa, serta (6) hasil belajar siswa rendah yakni rata-rata 5,09.

Agar pembelajaran IPS menjadi lebih aktif, kreatif, efektif, dan menyenangkan, dapat dilakukan dengan melalui berbagai cara. Salah satu cara yang cukup efektif adalah melalui penerapan model pembelajaran kooperatif dengan tipe STAD (Student Team Achievement Division). Pembelajaran kooperatif tipe STAD merupakan salah satu model pembelajaran yang konstruktivistik hal ini dilandasi oleh pemikiran bahwa siswa akan lebih mudah memahami dan menemukan konsep yang sulit apabila mereka mendiskusikan konsep yang sulit

2 Udin S Winatraputra, Materi dan Pembelajaran IPS SD, (Universitas Terbuka: Jakarta,2005), 3.3

AR-RIAYAH : Jurnal Pendidikan Dasar vol. 2, no. 2, 2018

STAIN Curup - Bengkulu| pISSN2580-362X;e ISSN2580-3611

http://journal.staincurup.ac.id/index.php/JPD 
tersebut dengan temannya, karena terkadang siswa lebih mudah memahami konsep-konsep materi pelajaran dengan bahasanya sendiri sehari-hari dibandingkan dengan cara penyampaian yang dilakukan oleh guru.

Jenis penelitian ini adalah Penelitian Tindakan Kelas (Classroom Action Research), yaitu merupakan jenis penelitian yang dilakukan oleh guru di dalam kelasnya melalui refleksi diri dengan tujuan untuk memperbaiki kinerjanya sebagai guru, sehingga hasil belajar siswa menjadi meningkat. Menurut Wardani Ada 4 tahapan penting dalam melaksanakan penelitian tindakan kelas yaitu: 1) perencanaan, 2) pelaksanaan, 3) pengamatan dan 4) refleksi. Keempat tahapan dalam penelitian ini merupakan unsur untuk membentuk sebuah siklus, yaitu satu putaran kegiatan beruntun yang kembali ke langkah semula atau siklus berulang $^{-3}$

\section{LANDASAN TEORI}

\section{Hakikat Belajar dan Pembelajaran}

Belajar pada hakikatnya merupakan proses perubahan di dalam kepribadian yang berupa kecakapan, sikap, kebiasaan, dan kepandaian. Perubahan ini bersifat menetap dalam tingkah laku yang terjadi sebagai suatu hasil dari latihan dan pengalaman Proses belajar tidak sekedar menghapal konsep-konsep atau fakta-fakta belaka, tetapi merupakan kegiatan menghubungkan konsep-konsep untuk menghasilkan pemahaman yang utuh, sehingga konsep yangdipelajari akan dipahami secara baik dan tidak mudah dilupakan. Menurut Gagne belajar merupakan sebuah sistem yang di dalamnya terdapat berbagai unsur yang saling terkait sehingga menghasilkan perubahan perilaku. $^{4}$

Pembelajaran merupakan tahapan-tahapan yang dilalui dalam mengembangkan kemampuan kognitif, afektif, dan psikomotorik seseorang, dalam hal ini adalah kemampuan yang harus dimiliki oleh siswa atau peserta didik. Salah satu peran yang dimiliki oleh seorang guru untuk melalui tahaptahap ini adalah sebagai fasilitator. Untuk menjadi fasilitator yang baik guru harus berupaya dengan optimal mempersiapkan rancangan pembelajaran yang sesuai dengan karakteristik anak didik, demi mencapai tujuan pembelajaran. Dalam pelaksanaan pembelajaran diperlukan suatu metode pembelajaran, yaitu suatu cara yang harus dilakukan dalam mengajar. Mengajar merupakan

\footnotetext{
${ }^{3}$ IGAK Wardhani dkk,Penelitian Tindakan Kelas, (Universitas Terbuka,Jakarta,2007), 2.4

${ }^{4}$ Gagne, Catharina Tri Anni, http://technonly13.wordpress.com.), di akses pada $12 \mathrm{Mei}$ 2017pukul 20.15 WIB
} 
penyajian bahan pelajaran oleh guru kepada siswa agar siswa dapat menerima, menguasai dan mengembangkan bahan pelajaran. Jadi belajar haruslah tepat dan efisien serta seefektif mungkin.

Sejalan dengan itu, Dimyati dan Mujiono, juga menjelaskan bahwa pembelajaran adalah kegiatan guru secara terprogram dalam desain instruksional, untuk membuat siswa belajar secara aktif, yang menekankan pada penyediaan sumber belajar. ${ }^{5}$ Dengan demikian dapat kita dirumuskan bahwa pembelajaran adalah suatu proses interaksi antara peserta didik dan pendidik dan sumber belajar yang dikelola untuk memungkinkan terjadinya prose belajar. Agar pembelajaran menyenangkan maka seorang guru harus dapat menentukan metode yang tepat dalam mengajar.

\section{Pendekatan Cooperative Learning}

Salah satu model pembelajaran yang sering digunakan adalah model pembelajaran kooperatif yaitu model pembelajaran yang merupakan strategi belajar melalui penempatan siswa belajar dalam kelompok kecil yang memiliki tingkat kemampuan yang berbeda. Dalam menyelesaikan tugas kelompok, setiap anggota saling bekerja sama dan membantu memahami suatu bahan pelajaran artinya bahan belum selesai jika salah satu teman dalam sekelompok belum menguasai bahan pembelajaran.

Davidson mendefinisikan belajar kooperatif adalah kegiatan yang berlangsung di lingkungan belajar siswa dalam kelompok kecil yang saling berbagi ide-ide dan bekerja secara kolaboratif untuk memecahkan masalahmasalah yang ada dalam tugas mereka. ${ }^{6}$ Hal ini diperkuat oleh pendapat Slavin cooperative learning adalah suatu pendekatan pembelajaran dimana siswa belajar dan bekerja dalam kelompok- kelompok kecil secara kolaboratif yang anggotanya terdiri dari 4- 6 orang dengan struktur kelompoknya bersifat heterogen. $^{7}$

Model pembelajaran kooperatif beranjak dari pemikiran Geeting Better Together, yang menekankan pada pemberian kesempatan belajar yang lebih luas dan suasana yang kondusif kepada siswa untuk memperoleh dan mengembangkan pengetahuan, sikap, nilai serta keterampilan-keterampilan

${ }^{5}$ Sagala,Konsep dan makna pembelajaran, (Alfabeta:Bandung), 3-5

${ }^{6}$ Nurasma,model pembelajaran kooperatif, (Depdiknas:Jakarta,2006),12.

7 Etin Solehatin,Cooperatif Learning Analisis Model Pembelajaran IPS, (Bumi aksara: Jakarta,2008), 52.

AR-RIAYAH : Jurnal Pendidikan Dasar vol. 2, no. 2, 2018

STAIN Curup - Bengkulu| pISSN2580-362X;e ISSN2580-3611

http://journal.staincurup.ac.id/index.php/JPD 
sosial yang bermanfaat bagi kehidupannya di masyarakat. Melalui model pembelajaran kooperatif siswa bukan hanya belajar dan menerima apa yang disajikan oleh guru dalam proses belajar mengajar, melainkan bisa juga belajar dari siswa lainnya dan sekaligus mempunyai kesempatan untuk membelajarkan siswa yang lain.

Pembelajaran kooperatif tidak hanya mempelajari materi saja, tetapi siswa juga harus mempelajari keterampilan-keterampilan khusus yang disebut keterampilan kooperatif. Keterampilan kooperatif berfungsi melancarkan hubungan kerja dan tugas. Peranan hubungan kerja dapat dibangun dengan mengembangkan komunikasi antar anggota kelompok, sedangkan peranan tugas dilakukan dengan membagi tugas antar anggota kelompok selama kegiatan berlangsung.

\section{Student Team-Achievement Division (STAD)}

STAD atau tim siswa kelompok prestasi merupakan salah satu sistem pembelajaran kooperatif yang di dalamnya siswa dibentuk ke dalam kelompok belajar terdiri dari empat atau lima anggota, mewakili siswa dengan tingkat kemampuan dan jenis kelamin yang berbeda, guru memberikan pelajaran dan selanjutnya siswa bekerja dalam kelompoknya masing-masing untuk memastikan bahwa semua anggota telah menguasai pelajaran yang telah diberikan, kemudian siswa melakukan tes materi yang diberikan dan mereka harus mengerjakan sendiri tanpa bantuan siswa lainnya. STAD dikembangkan untuk mencapai tiga tujuan penting yaitu prestasi belajar akademik, penerimaan terhadap keragaman atau perbedaan individu dan pengembangan keterampilan sosial.

Menurut Slavin Ada lima tahap proses kegiatan pembelajaran pendekatan kooperatif tipe STAD yaitu:

1. Tahap penyajian materi

Guru memulai dengan menyampaikan indikator yang harus dicapai dan memotivasi rasa ingin tahu siswa dari materi yang akan dipelajari. Dilanjutkan dengan memberika apersepsi, menyajikan materi, diskusi dan persentasi kelompok.

Dalam menyajikan materi pelajaran, guru memperhatikan hal-hal sebagai berikut:

a. Mengembangkan materi pelajaran sesuai dengan apa yang akan dipelajari siswa dalam kelompok. 
b. Menekankan kepada siswa bahwa belajar adalah memahami makna bukan hafalan.

c. Mengontrol pemahaman siswa .

d. Memberikan penjelasan tentang benar atau salahnya jawaban dari suatu pertanyaan.

Setelah siswa memahami permasalahan, selanjutnya beralih pada materi berikutnya.

2. Tahap kegiatan kelompok

Dalam tahap ini siswa mempelajari materi dan mengerjakan tugas-tugas yang diberikan guru berupa LKS. Dalam kegiatan kelompok siswa saling membantu, berbagi tugas. Setiap anggota kelompok bertanggung jawab atas kelompoknya. Peran guru dalam tahap ini sebagai fasilitator dan motivator kegiatan tiap kelompok.

3. Tahap pelaksanaan tes individu

Setelah materi dipelajari dan dibahas secara berkelompok, siswa diberi tes dengan tujuan untuk mengetahui sejauh mana keberhasilan yang telah dicapainya. Hasil tes digunakan sebagai nilai perkembangan individu dan untuk perolehan skor kelompok.

4. Tahap perhitungan skor perkembangan individu

Skor perkembangan individu dihitung berdasarkan selisih perolehan tes sebelumnya (skor awal) dengan tes akhir. Berdasarkan skor awal, setiap siswa memiliki kesempatan yang sama untuk memberikan sumbangan skor maksimal bagi kelompoknya berdasarkan skor tes yang diperolehnya.

5. Tahap penghargaan kelompok

Perhitungan skor kelompok dihitung dengan cara menjumlahkan tiap perkembangan skor individu dibagi jumlah anggota kelompok. ${ }^{8}$

\section{HASIL BELAJAR}

Menurut Dimyati dan Mudjiono hasil belajar merupakan hal yang dapat dipandang dari dua sisi yaitu sisi siswa dan dari sisi guru. Dari sisi siswa, hasil

\begin{tabular}{cccc}
\hline 8 & Isjoni,Kooperatif & Leraning efektifitas pembelajaran & kelompok, \\
Alfabeta:Bandung,2009, hlm 36 & &
\end{tabular}

AR-RIAYAH : Jurnal Pendidikan Dasar vol. 2, no. 2, 2018

STAIN Curup - Bengkulu| pISSN2580-362X;e ISSN2580-3611

http://journal.staincurup.ac.id/index.php/JPD 
belajar merupakan tingkat perkembangan mental yang lebih baik bila dibandingkan pada saat sebelum belajar.' Perolehan aspek-aspek perubahan tersebut tergantung pada apa yang dipelajari oleh pembelajar. Apabila pembelajar mempelajari pengetahuan tentang konsep, maka perubahan perilaku yang diperoleh adalah berupa penguasaan. Hasil belajar ini sangat dibutuhkan sebagai petunjuk untuk mengetahui sejauh mana keberhasilan siswa dalam kegiatan belajar yang sudah dilaksanakan. Hasil belajar dapat diketahui melalui evaluasi untuk mengukur dan menilai apakah siswa sudah menguasai ilmu yang dipelajari sesuai tujuan yang telah ditetapkan.

Hasil belajar di sekolah diutamakan pada aspek kognitif dimana aspek ini terdiri dari 6 tingkatan yaitu: tingkat pengetahuan (C1), Pemahaman (C2), Aplikasi (C3), Analisis (C4), Sintesis (C5), dan Evaluasi (C6), ( KTSP, 2006). Aspek kognitif pada tingkatan pengetahuan (C1), pemahaman (C2) dan aplikasi (C3), Analisis (C4), Sintesis (C5), akan lebih efektif apabila diajarkan dalam kelompok diskusi yang relatif kecil dan lebih dikembangkan pada sekolah dasar (SD). Kegiatan diskusi kelompok juga berperan sebagai alat yang sangat berpengaruh dalam mengintegrasikan pengembangan aspek kognitif setiap individu melalui pengalaman belajar.

\section{METODE PENELITIAN}

Jenis penelitian ini adalah Penelitian Tindakan Kelas (Classroom Action Research), yaitu merupakan jenis penelitian yang dilakukan oleh guru di dalam kelasnya melalui refleksi diri dengan tujuan untuk memperbaiki kinerjanya sebagai guru, sehingga hasil belajar siswa menjadi meningkat. Menurut Wardani Ada 4 tahapan penting dalam melaksanakan penelitian tindakan kelas yaitu: 1) perencanaan, 2) pelaksanaan, 3) pengamatan dan 4) refleksi. Keempat tahapan dalam penelitian ini merupakan unsur untuk membentuk sebuah siklus, yaitu satu putaran kegiatan beruntun yang kembali ke langkah semula atau siklus berulang $^{10}$

Penelitian ini dilaksanakan di ruang kelas dan dilakukan sebanyak 2 siklus, masing-masing siklus terdiri dari 4 tahap sebagai berikut: 1) Perencanaan, 2) Tindakan, 3) Pengamatan (Observasi), dan 4) Refleksi Ada pun setiap siklusnya dilakukan berdasarkan tindakan sebagai berikut:

9 Dimyati dan Mudjiono, Belajar dan Pembelajaran, Depdikbud Dirjen dikti, Jakarta, 1994, hlm 65

${ }^{10}$ IGAK Wardhani dkk,Penelitian Tindakan Kelas, (Universitas Terbuka:Jakarta,2007),2.4 


\section{Siklus I}

\section{Tahap Perencanaan Tindakan}

Adapun kegiatan yang akan dilakukan pada tahap ini adalah:

a. Menganalisis kurikulum dan silabus untuk menentukan Standar Kompetensi kelas IV semester II

b. Menentukan Kompetensi Dasar yaitu mengenal perkembangan teknologi produksi, komuniasi, dan transportasi serta pengalaman menggunakannya.

c. Membuat Rencana Pelaksanaan tentang perkembangan teknologi produksi, komuniasi, dan transportasi.

d. Membuat lembar observasi guru dan siswa yang digunakan untuk mengamati aktifitas guru dan siswa selama berlangsungnya kegiatan belajar mengajar dengan menggunakan penerapan pendekatan kooperatif tipe STAD.

e. Mempersiapkan alat-alat dan media yang akan digunakan pada waktu pembelajaran berlangsung berupa media gambar alat-alat produksi, komuniasi, dan transportasi.

f. Menyiapkan lembar diskusi siswa tentang perkembangan teknologi produksi, komunikasi, dan transportasi.

g. Menyusun alat evaluasi berupa soal pilihan ganda sebanyak 5 soal dan essay sebanyak 5 soal.

h. Menyiapkan reward untuk siswa berupa pin "excellent".

\section{Tahap Pelaksanaan Tindakan}

Pembelajaran pada siklus I merupakan pembelajaran IPS pada materi perkembangan teknologi dengan pendekatan Cooperative Learning Tipe STAD. Pada siklus I dilakukan sebanyak 3 kali pertemuan. Waktu pelaksanaan tindakan pada siklus I dapat dilihat pada tabel dibawah ini:

Tabel 1: Jadwal Pelaksanaan Tindakan Siklus I

\begin{tabular}{ccccc}
\hline No & $\begin{array}{c}\text { Pertemuan } \\
\text { ke }\end{array}$ & Tanggal & Waktu & Materi \\
\hline 1 & 1 & 21 April 2017 & $7.30-09.15$ WIB & $\begin{array}{c}\text { Teknologi } \\
\text { produksi }\end{array}$ \\
\hline
\end{tabular}




\begin{tabular}{ccccc}
\hline 2 & 2 & 24 April 2017 & $7.30-09.15$ WIB & $\begin{array}{c}\text { Teknologi } \\
\text { komunikasi }\end{array}$ \\
\hline 3 & 3 & 28 april 2017 & $7.30-09.15$ WIB & $\begin{array}{c}\text { Teknologi } \\
\text { transportasi }\end{array}$ \\
\hline
\end{tabular}

\section{Siklus II}

Langkah-langkah yang dilakukakan pada siklus I dilakukan lagi pada siklus II dengan beberapa perbaikan yang mengacu pada hasil refleksi terhadap apa yang dilakukan selama proses pembelajaran. Tindakan ini digunakan sebagai tolak ukur meningkatkan kualitas proses dan hasil belajar siswa pada mata pelajaran IPS dengan menggunakan pendekatan cooperative learning tipe STAD.

\section{Tahap persiapan}

Adapun kegiatan yang akan dilakukan pada tahap ini adalah:

a. Menganalisis kurikulum untuk menentukan standar kompetensi mata pelajaran IPS kelas IV semester II

b. Menentukan kompetensi dasar yaitu mengenal permasalahan sosial didaerahnya

c. Membuat Rencana Pelaksanaan Pembelajaran (RPP) tentang materi masalah sosial

d. Membuat lembar observasi guru dan siswa yang digunakan untuk mengamati aktifitas guru dan siswa selama berlangsungnya kegiatan belajar mengajar dengan menggunakan penerapan pendekatan kooperatif tipe STAD

e. Mempersiapkan alat-alat dan media yang akan digunakan pada waktu pembelajaran berlangsung grafik jumlah penduduk propinsi bengkulu dan gambar tentang permasalahan sosila yang sering terjadi

f. Menyiapkan lembar diskusi siswa (LDS) tentang permasalahan sosial

g. Menyusun alat evaluasi berupa soal pilihan ganda sebanyak 5 soal dan essay sebanyak 5 soal.

h. Menyiapkan reward untuk siswa berupa pin "excellent" dan piagam.

Tabel 2 : Jadwal Pelaksanaan Tindakan Siklus II 


\begin{tabular}{ccccc}
\hline No & $\begin{array}{c}\text { Pertemuan } \\
\text { ke }\end{array}$ & Tanggal & Waktu & Materi \\
\hline 1 & 1 & 03 Mei 2017 & $7.30-09.15$ WIB & $\begin{array}{c}\text { Masalah } \\
\text { kependudukan }\end{array}$ \\
\hline 2 & 2 & 9 Mei 2017 & $7.30-09.15$ WIB & Masalah social \\
\hline
\end{tabular}

\section{TEKNIK ANALISIS DATA} observasi.

Data yang diambil dalam penelitian ini ada dua yaitu data tes dan data

\section{Data observasi}

Data observasi digunakan untuk merefleksi kegiatan pembelajaran yang dilakukan pada siklus I. Ketentuan nilai dari data observasi menggunakan rumus:
a. Rata- rata skor
$=\frac{\text { jumlah skor }}{\text { jumlah observer }}$
b. Skor tertinggi = jumlah butir observasi $\mathrm{x}$ skor tertinggi tiap butir observasi
c. Skor terendah = jumlah butir observasi $\mathrm{x}$ skor terendah tiap butir observasi
d. Selisih skor
$=$ skor tertinggi - skor terendah
e. Kisaran nilai untuk tiap kriteria $=\frac{\text { selisih } \text { skor }}{\text { jumlah kriteria penialian }}$

\section{Data Tes}

Dianalisis dengan rata-rata nilai dan kriteria ketuntasan belajar berdasarkan penelitian acuan patokan. Menurut Depdiknas Siswa dikatakan tuntas belajar secara individual apabila siswa telah mencapai nilai 7,0 keatas secara klasikal proses belajar mengajar dikatakan tuntas bila siswa dikelas memperoleh nilai 70 keatas sebanyak 75\% dengan rumus sebagai berikut:

a. Rata-Rata Nilai

$$
\mathrm{X}=\frac{\Sigma x}{N}
$$

Keterangan

$$
\begin{array}{ll}
\mathrm{X} & =\text { Nilai rata-rata siswa } \\
\sum \mathrm{X} & =\text { Jumlah Nilai Siswa } \\
\mathrm{N} & =\text { Jumlah Siswa }
\end{array}
$$


b. Ketuntasan Belajar

$\mathrm{KB}=\frac{N S}{N} x 100 \%$

Keterangan:

$\mathrm{KB}=$ Ketuntasan Belajar

NS = Jumlah siswa yang mendapat nilai 7,0 ke atas

$\mathrm{N}=$ Jumlah seluruh siswa

Penilaian individu diperoleh dari hasil tes belajar siswa. Siswa dikatakan tuntas belajar secara individual apabila siswa telah mencapai nilai 70 keatas. Sedangkan untuk penilaian kelompok dapat dihitung dengan menggunakan rumus:

NK = Nilai materi (LDS) + Proses Diskusi Kelompok + Presentasi

Keterangan:

NK

$=$ Nilai Kelompok $(100 \%)$

Nilai materi(LDS)

$=50 \%$

Proses Diskusi Kelompok $=30 \%$

Presentasi

$=20 \%$

\section{HASIL PENELITIAN DAN PEMBAHASAN}

Tujuan penelitian ini bagaimana upaya meningkatkan hasil belajar siswa melalui pendekatan cooperative learning tipe STAD.

\section{Hasil Penelitian Siklus I}

Hasil observasi siklus 1 pada aktivitas siswa dapat di tunjukkan dalam table berikut:

Tabel 3: Hasil Analisis Data Observasi Siswa Siklus I

\begin{tabular}{cccccc}
\hline No & Pengamat & $\begin{array}{c}\text { Pertemuan } \\
\text { pertama }\end{array}$ & $\begin{array}{c}\text { Pertemuaan } \\
\text { kedua }\end{array}$ & $\begin{array}{c}\text { Pertemuan } \\
\text { ketiga }\end{array}$ & KET. \\
\hline 1 & 1 & 38 & 34 & 39 \\
\hline 2 & 2 & 33 & 37 & 36 \\
\hline Jumlah & 71 & 71 & 75 \\
\hline Rata-rata & 35,5 & 35,5 & 37,5 \\
\hline Jumlah & & 108,5 & \\
\hline Nilai akhir rata-rata & & 36,16 & \\
\hline
\end{tabular}


Kategori penilaian $\quad$ Baik

Berdasarkan hasil analisis keseluruhan data aktivitas siswa pada siklus 1 pertemuan 1, 2, dan 3 diperoleh nilai akhir rata-rata sebesar 36,16 yang termasuk kategori baik.

Tabel 4: analisis nilai akhir siswa siklus 1

\begin{tabular}{lc}
\hline Jumlah seluruh siswa & 24 orang \\
\hline Jumlah siswa yang mengikuti tes & 24 orang \\
\hline Jumlah siswa yang tuntas belajar & 14 orang \\
\hline Jumlah siswa yang tidak tuntas belajar & 10 orang \\
\hline Nilai rata-rata kelas & $\mathbf{6 0 , 7 9}$ \\
\hline Ketuntasan belajar klasikal & $\mathbf{5 8 , 3 3 \%}$ \\
\hline
\end{tabular}

\section{Hasil Penelitian Siklus II}

Hasil observasi siklus II terhadap analisis data aktivitas guru akan di tunjukkan pada tabel berikut:

Tabel 5: hasil analisis data observasi aktivitas guru siklus II

\begin{tabular}{ccccc}
\hline No & Pengamat & $\begin{array}{c}\text { Pertemuan } \\
\text { pertama }\end{array}$ & Pertemuaan kedua & KET. \\
\hline 1 & 1 & 39 & 44 \\
\hline 2 & 2 & 44 & 45 \\
\hline \multicolumn{3}{c}{ Jumlah } & 83 & 89 \\
\hline \multicolumn{2}{c}{ Rata-rata } & 41,5 & 44,5 \\
\hline \multicolumn{3}{c}{ Jumlah } & 86 \\
\hline Nilai akhir rata-rata & 43 \\
\hline Kategori penilaian & Sangat Baik \\
\hline
\end{tabular}

Berdasarkan hasil analisis keseluruhan data aktivitas guru pada siklus II pertemuan 1 dan 2 di peroleh nilai akhir rata-rata sebesar 43 yang termasuk kategori sangat baik.

\section{Tabel 6: hasil analisis data observasi siswa siklus II}


172 | AR-RIAYAH : Jurnal Pendidikan Dasar vol. 2, no. 2, 2018

\begin{tabular}{ccccc}
\hline No & Pengamat & Pertemuan pertama & Pertemuaan kedua & KET. \\
\hline 1 & 1 & 43 & 41 \\
\hline 2 & 2 & 45 & 51 \\
\hline Jumlah & 88 & 92 \\
\hline Rata-rata & 44 & 46 \\
\hline Jumlah & 90 \\
\hline Nilai akhir rata-rata & 45 \\
\hline Kategori penilaian & Sangat Baik \\
\hline
\end{tabular}

Berdasarkan hasil analisis keseluruhan data aktifitas siswa pada siklus II pertemuan 1 dan 2 diperoleh nilai akhir rata-rata sebesar 45 yang termasuk kategori sangat baik.

Tabel 7: analisis nilai akhir siswa siklus 2

\begin{tabular}{lc}
\hline Jumlah seluruh siswa & 24 orang \\
\hline Jumlah siswa yang mengikuti tes & 24 orang \\
\hline Jumlah siswa yang tuntas belajar & 21 orang \\
\hline Jumlah siswa yang tidak tuntas belajar & 3 orang \\
\hline Nilai rata-rata kelas & $\mathbf{7 2 , 4 7}$ \\
\hline Ketuntasan belajar klasikal & $\mathbf{8 7 , 5 \%}$ \\
\hline
\end{tabular}

\section{PEMBAHASAN}

\section{Siklus I}

Berdasarkan pengamatan yang dilakukan pengamat pada 3 pertemuan yang dilaksanakan selama tindakan siklus I skor rata- rata aktifitas guru hanya 36 dan berada dalam kategori baik. Sedangkan aktifitas siswa mendapatkan skor 36,16 dan berada dalam kategori baik. Meskipun skor aktifitas guru dan siswa berada pada ketegori baik, namun ada beberapa hal yang harus diperbaiki.

Hasil belajar siswa pada siklus I belum mencapai ketuntasan karena ketuntasan belajar secara klasikal hanya mencapai 58,33\% dan Rata - rata nilai pada siklus I hanya mencapai 60,79 sedangkan standar yang telah ditetapkan oleh Depdiknas (2006) yaitu $75 \%$ dan rata- rata nilai 70 . Pada siklus I diskusi belum berjalan dengan baik hal ini terlihat pada nilai akhir kelompok, hanya 3 kelompok saja yang mendapatkan nilai maksimal yaitu diatas 70 dari 7 kelompok yang ada. 
Rendahnya nilai di atas dikarenakan beberapa faktor. Baik dari siswa maupun dari guru. Faktor penyebab rendahnya nilai pada siklus I antara lain: 1).guru kurang mampu menggunakan pendekatan cooperative learning tipe STAD, 2).guru kurang memahami karakteristik siswa, 3). guru belum terlalu mahir dalam mengelola kelas, 4). minat siswa untuk belajar rendah.

Hal-hal yang perlu dilakukan agar hasil belajar siswa meningkat pada siklus II antara lain: (1) Guru harus memahami tahapan pembelajaran menggunakan pendekatan cooperative learning tipe STAD;(2) Guru harus memahami karakteristik siswa; (3) Guru harus mampu mengelola kelas, dan (4) Guru harus menarik minat siswa.

\section{Siklus II}

Berdasarkan pengamatan yang dilakukan pengamat pada 2 pertemuan yang dilaksanakan selama pembelajaran siklus II skor rata- rata aktifitas guru hanya 43 dan berada dalam kategori sangat baik. Sedangkan aktifitas siswa mendapatkan skor 45 dan berada dalam kategori sangat baik.

Hasil belajar siswa pada siklus II sudah mencapai ketuntasan belajar secara klasikal yang ditetapkan oleh Depdiknas sebesar $75 \%$ yaitu mencapai $87,5 \%$ dan Rata - rata nilai pada siklus II telah mencapai 72,47. Pada siklus II diskusi sudah berjalan dengan baik hal ini terlihat pada nilai akhir kelompok. Dari 7 kelompok hanya 1 kelompok saja yang mendapatkan nilai dibawah 70 .

Berdasarkan uraian di atas dapat dijelaskan bahwa kemampuan guru dalam melaksanakan proses pembelajaran telah meningkat. Hal ini terlihat pada perolehan rata-rata skor aktivitas guru yang mengalami peningkatan dari 36 dengan kategori "Baik" meningkat menjadi 43 dengan kategori "Sangat Baik", sehingga dapat diartikan bahwa kualitas proses pembelajaran sudah meningkat.

Peningkatan yang terjadi tidak dapat dilepaskan dari usaha guru dalam memperbaiki proses pembelajaran. Pada siklus II guru sudah menguasai materi pembelajaran, memahami karakteristik siswa, dan sudah mampu mengelola kelas dengan baik. Dalam mengelola kelas sebaiknya guru harus memperhatikan prinsip-prinsip tersebut sehingga proses pembelajaran bisa berjalan dengan baik dan bermakna. Peningkatan aktifitas guru pada tiap siklus dapat dilihat pada grafik di bawah ini.

Grafik 1 : peningkatan aktivitas guru pada tiap siklus

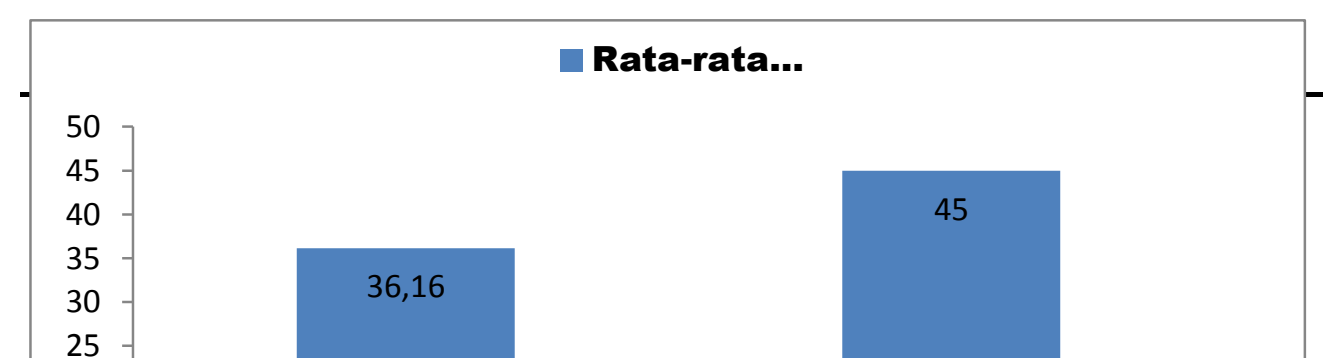


174 | AR-RIAYAH : Jurnal Pendidikan Dasar vol. 2, no. 2, 2018

Pada pengamatan Aktivitas siswa terjadi peningkatan pada siklus II. Hal ini dapat dilihat dari rata-rata skor lembar observasi siswa pada siklus I hanya mencapai 36,16 dengan kategori "Baik" dan meningkat pada siklus II menjadi 45 dengan kategori "Sangat Baik", sehingga dapat diartikan bahwa kualitas proses pembelajaran sudah meningkat.

Hasil pengamatan aktivitas siswa siklus II ini menunjukkan hasil yang sangat memuaskan. Peningkatan ini dipengaruhi oleh motivasi siswa untuk mengikuti pembelajaran. Peningkatan skor aktifitas siswa pada tiap siklus dapat dilihat pada grafik dibawah ini:

Grafik 2: peningkatan aktivitas siswa pada tiap siklus

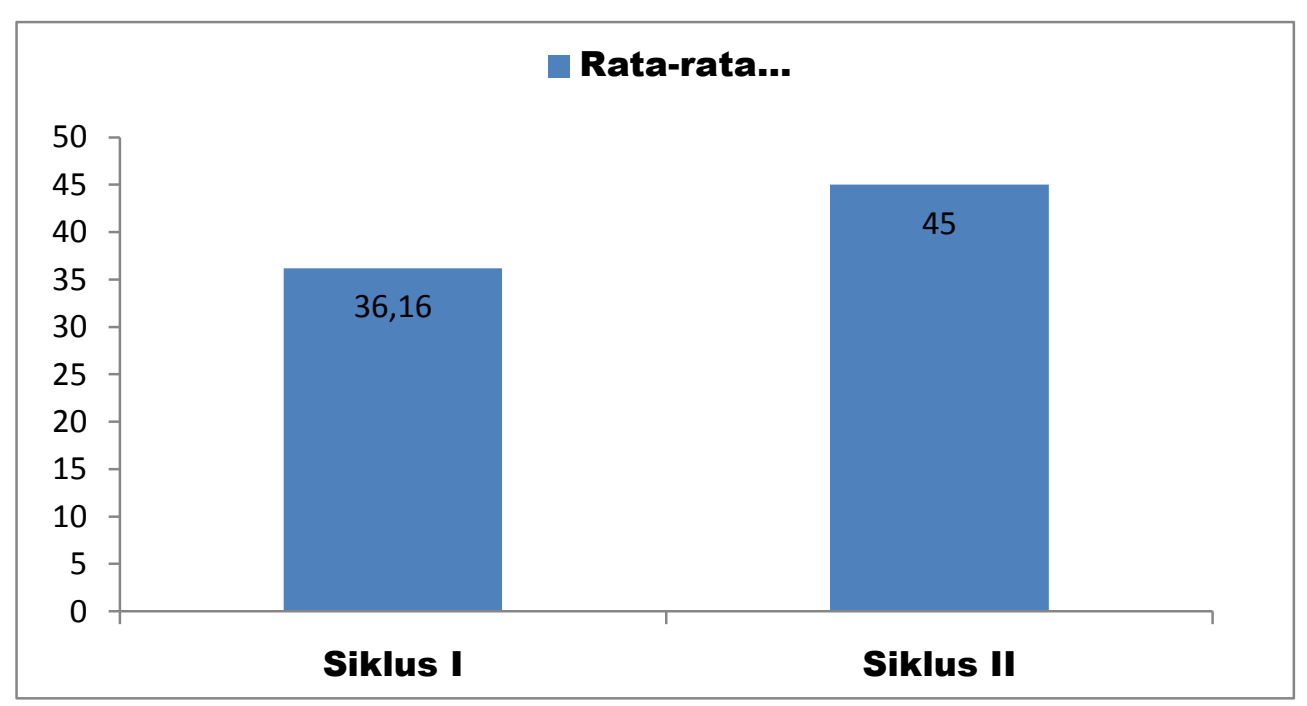


Selain itu, aktivitas siswa juga meningkat pada siklus II ini karena penguatan yang diberikan guru sangat bermakna berupa pin "excellent" dan piagam. Penguatan ini bertujuan untuk meningkatkan perhatian siswa terhadap pembelajaran, merangsang dan meningkatkan motivasi belajar, meningkatkan kegiatan belajar, dan membina perilaku yang produktif.

Dalam suatu pembelajaran, dua hal penting yang tidak dapat dipisahkan adalah hasil belajar dan proses pembelajaran itu sendiri. Pada siklus I, rata-rata nilai yang diperoleh adalah 60,79 dengan ketuntasan belajar klasikal 58,33\% . Hal ini erat kaitannya dengan kurang maksimalnya proses pembelajaran pada siklus I yang tercermin pada aktivitas guru dan aktivitas siswa. Sedangkan pada siklus II, tergambar bahwa aktivitas guru dan aktivitas siswa meningkat sehingga hasil belajar siklus II pun meningkat. Rata-rata nilai pada siklus II mencapai 72,47 dengan ketuntasan belajar klasikal 87,5\%.

Pada pembelajaran IPS dengan menerapkan pendekatan cooperative learning tipe STAD penilaian kelompok dihitung dari tiga aspek yaitu nilai LDS, proses diskusi, dan presentasi. Pada siklus I hanya 3 kelompok siswa saja yang mendapat nilai di atas 70 dari 7 kelompok siswa yang ada. Pada Siklus II, proses diskusi siswa meningkat dan sudah berjalan dengan baik. Hal ini menyebabkan nilai akhir kelompok yang maksimal. Hanya 1 kelompok saja yang mendapatkan nilai kurang maksimal dari 7 kelompok yang ada. Hal ini dapat dikatakan bahwa proses pembelajaran berhasil dan meningkat.

\section{KESIMPULAN}

Pendekatan Cooperative Learning tipe STAD pada mata pelajaran IPS dapat meningkatkan kualitas proses pembelajaran. Hal ini ditunjukkan dari ratarata hasil analisis data observasi guru pada siklus I adalah 36 dengan kategori "Baik" dan mengalami peningkatan pada siklus II sebesar 43 dengan kategori "Sangat Baik". Di samping itu data observasi siswa pada siklus I 36,16 dengan kategori "Baik" dan meningkat pada siklus II yaitu 45 dengan kategori "Sangat Baik". Penerapan Pendekatan Cooperative Learning tipe STAD pada mata pelajaran IPS dapat meningkatkan hasil belajar yang ditunjukkan dengan hasil ketuntasan belajar klasikal yaitu siklus I mencapai 58,33\% dan nilai rata-rata 60,79 meningkat pada siklus II yaitu ketuntasan belajar klasikal mencapai 87,5 $\%$. dan nilai rata-rata. 72,47 .

\section{DAFTAR PUSTAKA}

Asma, Nur.2006. Model Pembelajaran Kooperatif. Jakarta. Depdiknas

AR-RIAYAH : Jurnal Pendidikan Dasar vol. 2, no. 2, 2018

STAIN Curup - Bengkulu| pISSN2580-362X;e ISSN2580-3611

http://journal.staincurup.ac.id/index.php/JPD 
176 | AR-RIAYAH : Jurnal Pendidikan Dasar vol. 2, no. 2, 2018

Darman, Flavianus, dkk. 2007. UU No. 20 Th. 2003 Tentang Sistem Pendidikan Nasional dan UU No. 14 Th. 2005 Tentang Guru dan Dosen. Jakarta: Visimedia.

Depdikbud.(2006). Kurikulum Tingkat Satuan Pendidikan. Jakarta: Pusat

Dimyati dan Mudjiono. 1994. Belajar dan pembelajaran. Jakarta: Depdikbud

Dirjen Dikti.

Isjoni, 2009. Kooperatif learning efektifitas pembelajaran kelompok. Bandung.: Alfabeta.

Sagala, 2006. Konsep dan Makna Pembelajaran. Bandung: Alfabeta.

Solihatin, Etin 2008. Cooperative Learning analisis Model pembelajaran IPS. Jakarta: Bumi Aksara.

Wardani I.G.A.K, Dkk. 2004. Penelitian Tindakan Kelas. Jakarta: Universitas Terbuka.

Winataputra, Udin S.2005. Materi dan Pembelajaran IPS SD. Jakarta: Universitas Terbuka. 